\title{
Article/Artigo
}

\section{Assessment of integration of the Leprosy Program into Primary Health Care in Aracaju, State of Sergipe, Brazil}

\author{
Avaliação da integração do Programa de Hanseníase na Atenção Primária em Aracaju, Estado \\ de Sergipe, Brasil
}

\section{Marcos Túlio Raposo ${ }^{1}$ and Maria Ines Battistella Nemes ${ }^{2}$}

\section{ABSTRACT}

Introduction: The aim of this study was to assess the epidemiological and operational characteristics of the Leprosy Program before and after its integration into the Primary Healthcare Services of the municipality of Aracaju-Sergipe, Brazil. Methods: Data were drawn from the national database. The study periods were divided into preintegration (1996-2000) and postintegration (2001-2007). Annual rates of epidemiological detection were calculated. Frequency data on clinico-epidemiological variables of cases detected and treated for the two periods were compared using the Chi-squared $\left(\chi^{2}\right)$ test adopting a $5 \%$ level of significance. Results: Rates of detection overall, and in subjects younger than 15 years, were greater for the postintegration period and were higher than rates recorded for Brazil as a whole during the same periods. A total of 780 and 1,469 cases were registered during the preintegration and postintegration periods, respectively. Observations for the postintegration period were as follows: I) a higher proportion of cases with disability grade assessed at diagnosis, with increase of $60.9 \%$ to $78.8 \%$ ( $p<0.001$ ), and at end of treatment, from $41.4 \%$ to $44.4 \%$ ( $p<0.023$ ); II) an increase in proportion of cases detected by contact examination, from $2.1 \%$ to $4.1 \%$ $(\mathrm{p}<0.001)$; and III) a lower level of treatment default with a decrease from 5.64 to 3.35 $(p<0.008)$. Only $34 \%$ of cases registered from 2001 to 2007 were examined. Conclusions: The shift observed in rates of detection overall, and in subjects younger than 15 years, during the postintegration period indicate an increased level of health care access. The fall in number of patients abandoning treatment indicates greater adherence to treatment. However, previous shortcomings in key actions, pivotal to attaining the outcomes and impact envisaged for the program, persisted in the postintegration period.

Keywords: Leprosy. Epidemiology. Program and project evaluation. Family health. Primary health care.

\section{RESUMO}

Introdução: $\mathrm{O}$ estudo avalia características epidemiológicas e operacionais do programa de hanseníase no período anterior e posterior à integração nos serviços de Atenção Primária do município de Aracaju-Sergipe, Brasil. Métodos: Os dados foram obtidos da base nacional. O período estudado foi dividido em pré-integração (1996-2000) e pós-integração (20012007). Calcularam-se os indicadores epidemiológicos de detecção ano a ano. Frequências de variáveis clínico-epidemiológicas dos casos detectados e tratados foram comparadas entre os dois períodos utilizando-se qui-quadrado $\left(\chi^{2}\right)$ com nível de significância de $5 \%$. Resultados: As taxas de detecção geral e em menores de 15 anos aumentaram no pós-integração e se mantiveram acima das obtidas para o Brasil em ambos os períodos. Houve 780 e 1.469 casos nos períodos pré e pós-integração, respectivamente. No período pós-integração, observouse: aumento na proporção de casos com grau de incapacidade avaliado ao diagnóstico, de $60,9 \%$ para $78,8 \%(\mathrm{p}<0,001)$ e, ao final do tratamento, de $41,4 \%$ para $44,4 \%(\mathrm{p}<0,023)$ aumento na proporção de casos detectados por exame de contatos, de $2,1 \%$ para $4,1 \%$ $(\mathrm{p}<0,001)$; diminuição do abandono de tratamento de 5,64 para 3,35 ( $\mathrm{p}<0,008)$. Apenas 34\% dos contatos registrados nos anos 2001-2007 foram examinados. Conclusões: As oscilações verificadas nas taxas de detecção geral e em menores de 15 anos no período pós-integração sugerem ter havido incremento no acesso. A redução do número de abandonos indica melhora na adesão ao tratamento. Insuficiências pré-existentes em ações de importância crucial para os resultados e impactos esperados do programa persistiram no período pós-integração.

Palavras-chaves: Hanseníase. Epidemiologia. Avaliação de programas e projetos. Saúde da família. Atenção primária.

1. Departamento de Saúde, Universidade Estadual do Sudeste da Bahia, Jequié, BA. 2. Departamento de Medicina Preventiva, Faculdade de Medicina, Universidade de São Paulo, São Paulo, SP.

Address to: Marcos Túlio Raposo. Departamento de Saúde/UESB. Av. José Moreira Sobrinho s/n, Jequiezinho, 45200-000 Jequié, BA, Brasil.

Phone: 5573 3528-9609.

e-mail: tulio.raposo@hotmail.com

Received in 30/04/2011

Accepted in 19/09/2011

\section{INTRODUCTION}

In Brazil, actions for diagnosing and treating leprosy have historically been conducted at specialized state-run units. Since 1994, Brazil's Ministry of Health has devised and promoted the Family Health Strategy (FHS) as a priority model for organizing primary health care services. In response to initiatives by the World Health Organization (WHO) recommending integration of leprosy control into primary health care (PHC), Brazil has established the integration of leprosy control actions (LCA) into primary health care as a key directive toward achieving the goal of eliminating leprosy ${ }^{1}$. Thus, the main strategy proposed for implementing leprosy actions was training family health care teams (FHCT), through training courses and distribution of technical guides.

The FHS was implemented in Acaraju in $1998^{2}$. Integration of the LCA began only in 2000 following training of $\mathrm{FHCT}^{3}$. In 2007, the municipality had 128 FHCT, distributed among 43 family health units, providing coverage for $86.7 \%$ of the population $^{2}$.

Traditionally, appraisals of the performance of the Leprosy Control Program (LCP) have been based on a set of indicators defined by the National LCP, compiled from information contained in notification/investigation records held on the Brazilian Disease Notification System (Sistema de Informação de Agravos de Notificação - SINAN), a system developed in the 1990 s as a tool for collecting, processing, storing, and analyzing data on mandatory notifiable diseases in Brazil ${ }^{4}$. These indicators are categorized into two groups denoted by the Ministry of Health as epidemiologic and operational ${ }^{5}$. However, the use of these indicators for assessment purposes has several drawbacks. One of these weaknesses is the lack of robustness of the information sourced from data collected at local and municipal levels. Many municipalities lack adequate systems to oversee data entry into the system or to monitor the information held. Nevertheless, for states and municipalities in which 
the system is well managed, the assessment of information from the system enables valuable analyses, which help managers assess and monitor local actions ${ }^{6}$.

In this regard, the use of data from SINAN for individual municipalities and locales is potentially positive. Reports have described highly heterogeneous situations among different municipalities from within the same area or even across services offered by the same municipality. Greater proximity of the action agents, namely, health care managers and professionals, with these data increases the likelihood of the information leading to improvements.

The aim of the present study was to analyze the epidemiological indicators and the clinico-epidemiological characteristics of leprosy during the preintegration and postintegration periods of LCA at family health units in the municipality of Aracaju.

\section{METHODS}

This descriptive study involved analysis spanning 12 years ( Jan 1996 to Dec 2007) and was restricted to diagnosed cases of leprosy in patients residing in the municipality of Aracaju in Sergipe, Brazil. Data were sourced from the SINAN through the Aracaju Municipal Secretariat for Health and the State Secretariat for Health of Sergipe. In a bid to increase the reliability of the data and reduce the risk of under-registration, the study used data collected in 2009 on the years 1996 to 2007.

Aracaju, the capital of State of Sergipe, covers an area of $174 \mathrm{~km}^{2}$ and had an estimated population of 544,035 inhabitants in 2009. The city accounts for the highest number of leprosy cases in the state and had an overall detection rate of 49.22 cases for every 100,000 inhabitants in $2007^{7}$. The integration of the LCP into family health units commenced in $2000^{3}$, and therefore, the analysis was split into two study periods: the 1996 to 2000 period corresponded to the phase prior to the integration of the LCA and was denoted the preintegration period, and the period spanning from 2001 to 2007 represented the postintegration period.

The database was organized to ensure exclusion of duplicate and inconsistent records. Individual compulsory notification records and/or clinical charts were analyzed in the remaining cases of inconsistencies. To standardize the records for current classification, cases with a disability grade 3 , registered up to 2001, were converted to grade 2 disability, in accordance with the instrument standardized by the WHO, revised in 1998, and adopted in Brazil.

Given that leprosy detection rates fluctuate over longer periods, to assess the endemic picture for the municipality, a descriptive analysis of the indicators recommended for monitoring and assessing the epidemic, compiled on an annual basis encompassing aspects of morbidity, magnitude, and epidemiological profile, was carried out ${ }^{5}$.

The following indicators were included: annual rate of detection of new cases per 100,000 inhabitants, annual rate of detection of new cases in the population aged between 0 and 14 years per 100,000 inhabitants ${ }^{5}$, and proportion of disability grade 2 in new cases per 1 million inhabitants at time of diagnosis ${ }^{8}$. Because of the inconsistency of some of the variables held on the database, the following indicators were excluded: proportion of leprosy cases with grade 2 physical disability on diagnosis among new cases detected and assessed on an annual basis and proportion of leprosy cases with grade 2 physical disability among cases assessed at conclusion of multidrug therapy (MDT) on an annual basis. It was decided not to use the rate of annual prevalence of leprosy per 10,000 inhabitants because of the change in the criteria used to calculate this figure during the study period and also owing to the intrinsic weakness in the prevalence indicator currently in use.

From the year of initial diagnosis, the clinico-epidemiological variables were taken (gender, age-group, operational classification, disability grading (DG) rating at diagnosis, DG rating at end of treatment (MDT), detection method, contacts examined, and case outcome) as a proxy representing the quality of the service. The evolution of these variables over time was analyzed for the two time frames studied. The first period was the preintegration stage, characterized by a health care service centralized at a single health unit, whereas the second encompassed the postintegration period, during which, the LCA were integrated into PHC.

Data were stored on the EpiInfo ${ }^{\text {тм }}$ software program, version 3.3, from the Centers for Disease Control and Prevention (CDC), October 2004. Frequency distributions were compared using the Chi-squared $\left(\chi^{2}\right)$ test adopting a $5 \%$ level of significance $(\mathrm{p}<0.05)$.

\section{Ethical considerations}

The project was previously approved by the Research Ethics Committee of the Clinics Hospital, University of São Paulo Medical School ( $\left.{ }^{\circ} 1032 / 08\right)$ and by the Research Ethics Committee of Tiradentes University $\left(\mathrm{n}^{\circ} 030108\right)$.

\section{RESULTS}

\section{Detection rates}

From 1996 to 2007, a total of 2,249 cases of leprosy were detected in Aracaju, the municipality with the highest number of cases of the disease in Sergipe. Table 1 shows data obtained by this study set against official figures on the epidemic in Brazil ${ }^{9}$. Shifts over the period point to an increase in overall detection during the years subsequent to integration of the LCP in PHC in 2000. A peak in detection was found in 2003, reaching a rate of over 50/100,000 inhabitants, a level maintained for the two proceeding years.

The raw rates of detection in individuals between 0 and 14 years of age showed some variations, predominantly during the period following integration, peaking both in 2002 and 2005 when the detection rate reached its highest point of more than double the rate for the previous year. The trend in the detection rate in children revealed a pattern of a slight rise, where rates for Sergipe consistently exceeded those of Brazil as a whole for almost all years studied'

Taken together, the overall detection rate between 2003 and 2006, plus the detection rate among individuals younger than 15 years, classify the municipality as hyper-endemic. During the other years studied, the pattern of the epidemic was classified as very high ${ }^{5}$. The shift in the epidemiological picture for the disease coincided with the rising number of FHCTs incorporated into PHC and with the intensifying of the process of implementing the FHS in the municipality.

The proportion of new cases rated as DG2 at diagnosis (per million inhabitants) was calculated only for years in which the DG percentage assessed at diagnosis exceeded $75 \%$. For the years 2001 , 2002 , 2003, 2005, and 2006, the proportion of cases (per million inhabitants) showed a stable pattern with rates of 14.95, 12.66, 27.1, 16.04 , and 11.87 , respectively. 
TABLE 1 - Epidemiological indicators for leprosy from 1996 to 2007.

\begin{tabular}{|c|c|c|c|c|c|}
\hline \multirow[b]{2}{*}{ Period } & \multirow[b]{2}{*}{ Year } & \multicolumn{2}{|c|}{$\begin{array}{c}\text { Overall detection rate } \\
\text { (per } 100,000 \text { population) }\end{array}$} & \multicolumn{2}{|c|}{$\begin{array}{c}\text { Detection rate in individuals } \\
<15 \text { years (per100,000 population) }\end{array}$} \\
\hline & & Brazil $^{*}$ & Aracaju $^{* *}$ & Brazil $^{*}$ & Aracaju $^{* *}$ \\
\hline \multirow[t]{5}{*}{ Preintegration } & 1996 & 25.79 & 41.1 & 7.5 & 13.29 \\
\hline & 1997 & 28.27 & 28.52 & 8.28 & 7.7 \\
\hline & 1998 & 26.23 & 30.9 & 7.86 & 9.89 \\
\hline & 1999 & 26.6 & 37.03 & 7.3 & 9.1 \\
\hline & 2000 & 25.44 & 38.78 & 6.72 & 7.82 \\
\hline \multirow[t]{7}{*}{ Postintegration } & 2001 & 26.61 & 31.81 & 6.96 & 5.39 \\
\hline & 2002 & 28.33 & 35.65 & 7.47 & 13.7 \\
\hline & 2003 & 29.37 & 53.56 & 7.98 & 13.54 \\
\hline & 2004 & 28.24 & 50.04 & 7.68 & 15.61 \\
\hline & 2005 & 26.86 & 51.94 & 7.34 & 18.09 \\
\hline & 2006 & 23.37 & 41.95 & 6.22 & 8.57 \\
\hline & 2007 & 21.19 & 35.16 & 6.07 & 6.94 \\
\hline
\end{tabular}

${ }^{*}$ Brazil's Ministry of Health ${ }^{8}{ }^{* *}$ Database used by the study.

\section{Clinico-epidemiological characteristics of cases}

With regard to gender for the study period as a whole, the cases were predominantly women, but the gender distribution for the two study periods did not differ significantly $(\mathrm{p}=0.164)$.

Of the 2,249 cases included, 2,077 (92.4\%) were older than fifteen years when first diagnosed. Comparing the two study periods, the proportion of leprosy patients aged between 0 and 14 years was $8 \%$ and $7.32 \%$ for preintegration and postintegration periods, respectively, a difference not reaching statistical significance $(\mathrm{p}=0.696)$. A total of $351 / 780(45 \%)$ cases in the age bracket of 20 to 44 years were diagnosed during the preintegration period versus $707 / 1,469$ (48.3\%) during the postintegration period.

TABLE 2 - Clinico-epidemiological variables by period of integration of leprosy control actions into health care services.

\begin{tabular}{|c|c|c|c|c|c|}
\hline \multirow[b]{2}{*}{ Variable } & \multicolumn{2}{|c|}{ 1996-2000 } & \multicolumn{2}{|c|}{ 2001-2007 } & \multirow{2}{*}{$\begin{array}{c}\mathbf{p} \\
\text { value }\end{array}$} \\
\hline & $\mathbf{n}$ & $\%$ & $\mathbf{n}$ & $\%$ & \\
\hline \multicolumn{6}{|c|}{ Disability grade at diagnosis $(n=2,249)$} \\
\hline DG 0 and 1 & 457 & 58.6 & 1,090 & 74.2 & $<0.001$ \\
\hline DG 2 & 18 & 2.3 & 57 & 3.9 & \\
\hline unknown & 305 & 39.1 & 322 & 21.9 & \\
\hline Total & 780 & 100.0 & 1,469 & 100.0 & \\
\hline \multicolumn{6}{|c|}{ Disability grade at end of multidrug therapy $(n=2,249)$} \\
\hline DG 0 and 1 & 321 & 41.15 & 631 & 42.95 & $<0.023$ \\
\hline DG 2 & 2 & 0.26 & 20 & 1.36 & \\
\hline unknown & 457 & 58.59 & 818 & 55.68 & \\
\hline Total & 780 & 100.0 & 1,469 & 100.0 & \\
\hline \multicolumn{6}{|c|}{ Detection method $(n=2,249)$} \\
\hline contact examination & 16 & 2.1 & 60 & 4.1 & $<0.001$ \\
\hline others & 756 & 96.9 & 1,312 & 89.3 & \\
\hline unknown & 8 & 1.0 & 97 & 6.6 & \\
\hline Total & 780 & 100.0 & 1,469 & 100.0 & \\
\hline \multicolumn{6}{|c|}{ Treatment outcome $(n=2,213)$} \\
\hline treatment completed & 701 & 89.9 & 1,293 & 90.2 & $<0.008$ \\
\hline defaulter & 44 & 5.6 & 48 & 3.4 & \\
\hline others & 35 & 4.5 & 92 & 6.4 & \\
\hline Total & 780 & 100.0 & 1,433 & 100.0 & \\
\hline
\end{tabular}

The majority of cases detected were of the paucibacillary (PB) type for both study periods. Although an increase in multi-bacillary (MB) cases was seen (from $36.2 \%$ to $40 \%$ ), this difference was not statistically significant $(\mathrm{p}=0.073)$.

Table 2 shows the epidemiological variables by period of LCA integration in the municipality.

The proportion of new cases with DG rated at diagnosis was $60.9 \%$ and $78.1 \%$ for preintegration and postintegration periods, respectively. A decrease in the percentage of cases in which DG was not rated was found for the postintegration period $(\mathrm{p}<0.001)$.

Analysis of DG assessment at end of treatment revealed that DG was not rated in $58.6 \%$ and $55.7 \%$ of cases during preintegration and postintegration periods, respectively, where the reduction in cases without registered disability reached statistical significance for the postintegration period $(\mathrm{p}<0.023)$.

In terms of detection method, a significant association $(\mathrm{p}<0.001)$ was found with probable increased detection by contact examination, following the integration of LCA to PHC. Entry to the system as relapsing was included in this study under the category of other methods of detection, and from 1996 to 2000, only 3/780 $(0.4 \%)$ of cases were entered as relapsing, whereas from 2001 to $2007,59 / 1,469$ (4\%) of cases were registered under this mode of entry (data not shown in Table 2).

With regard to the number of patients undergoing treatment during the years assessed, 106/780 (13.6\%) and $1,014 / 1,469(69 \%)$ of patients had their contacts registered during preintegration and postintegration periods, respectively. The proportion of contact examinations per new 
leprosy case was $568 / 780$ (0.73) during the preintegration period versus $2,100 / 1,469$ (1.43) for the postintegration period, showing improved compliance with the contact examination action.

Concerning the type of outcome registered, a significant reduction in the percentage of defaulters was found for the postintegration period $(\mathrm{p}<0.008)$.

\section{DISCUSSION}

Comparing raw rates of detection overall, from 1996 to 2007, the epidemic was consistently worse in Aracaju than in Brazil as a whole for virtually all years studied ${ }^{9}$. These results point to an overall increase in detection after the integration of the LCP into PHC.

Worldwide, the trend in the rates of detection of new cases showed no decline between 1995 and $2000^{10}$, but a downward shift was evident from 2002 to $2008^{11}$. In India, the country with the highest number of leprosy cases, the rate of detection steadily increased between 1982 and $2002^{12}$. A similar steady upward trend also has been seen in Latin America ${ }^{10}$. Brazil accounts for over $90 \%$ of cases found in South America, and detection rates between 1980 and 2004 showed a steady rise $e^{13,14}$ with levels set to fall from $2010^{13}$. For the North-East region of Brazil in particular, the largest increase in detection rates occurred between 1980 and 2004, although this area also had a higher regression rate than any other region in the country ${ }^{14}$.

The upward shift in detection rates seen in Aracaju is similar to the trend reported in other Brazilian studies ${ }^{15-19}$, but a steady decline is evident from 2003 onward. These results contrast with the pattern reported for states in the process of eliminating the disease as a public health problem, such as Paraná ${ }^{20}$ and São Paulo ${ }^{21}$, which exhibited a pattern of steady decline in detection rates over the same time frame.

The relatively stable pattern of detection rates in individuals between 0 and 14 years of age, with a marked rise during the postintegration period, is consistent with a study conducted in Duque de Caxias where twin peaks of detection were identified in this age group. This double-peak pattern may be explained by the initial phase of integration or strategic actions carried out the previous year ${ }^{16}$.

Other studies in Brazil involving individuals younger than 15 years have revealed a pattern of endemicity varying from average to very high ${ }^{18,22,23}$. Rates for the Vale do Jequitinhonha were found to exceed those State of Minas Gerais, where parameters for the region were responsible for sustaining the epidemic and contributed to its classification of high to very high ${ }^{24}$. In the State of Espírito Santo, analysis of the trend of detection in individuals under 15 years of age showed an upward pattern between 1980 and 2003, with rates stabilizing between 1996 and $2003^{19}$. Although other studies have shown similar slight increases in detection in children ${ }^{25}$ or have pointed to a steady pattern over time ${ }^{26}$, a study in a historic series performed in Bahia is noteworthy. The cited study found a substantial increase in the rate of detection among minors over the past two decades ${ }^{15}$, demonstrating the recent surge in transmission of the epidemic ${ }^{5}$.

Frequency of new cases with DG 2 at diagnosis is a recent measure currently calculated per 1 million inhabitants ${ }^{8}$, which is employed to assess the magnitude of deformity caused by leprosy in the general population, to compare it against other diseases, and to indicate the efficacy of early case detection ${ }^{5}$. The measure currently lacks parameters defined by WHO or the Brazilian Ministry of Health to aid its interpretation. Nevertheless, the world target is to reduce this figure by at least $35 \%$ between 2011 and 2015, whereas the target for Brazil is a $13 \%$ reduction from 2008 to $2015^{5}$. Despite the accuracy issues associated with this indicator because of the characteristics of the epidemic and to the limited knowledge of the operational reality of actions in each country, the measure can contribute toward improving the quality of leprosy services ${ }^{27}$. The limitation of this study in interpreting this indicator may be attributable to the lack of data or to the under-reporting of physical disabilities at diagnosis, particularly from 1996 to 2000, during which time, the mean percentage of DG assessment was less than $75 \%$. However, inconsistencies in data regarding disability registration, particularly in the first few years of the series analyzed, must be taken into account.

Biological and sociocultural factors have been implicated as determinants of the greater incidence of leprosy found in men ${ }^{28}$. Other studies carried out in Brazil have confirmed the disease's predominance in male subjects ${ }^{19,29-31}$. However, the greater number of women found in the years assessed in the present study is in line with the findings of other investigations ${ }^{16,32-35}$. One possible explanation for this phenomenon is that traditionally, women have a tendency to seek PHC assistance more readily than men $^{28,36}$. This difference is due to cultural gender issues (men delay longer in seeking medical help when ailing), as well as to the greater number of programs and activities available to women in the primary health care sphere.

The predominance of young adults observed in the present cases is consistent with other reports ${ }^{17,29,30,32,33,35,37,38}$. This population group is more vulnerable to the risk of exclusion from the production cycle as a result of the disease and to the sequelae and stigma associated with leprosy $y^{39}$. The percentage of individuals aged between 0 and 14 years afflicted by the disease may be a sign of active and recent transmission of the endemic, with under 15 s being continuously exposed to the bacillus in the environment where they live ${ }^{4}$. This result also exposes the passive stance of local health services and limited efforts to actively identify cases ${ }^{24}$ or implement other means of health surveillance.

Some Brazilian studies have confirmed the predominance of the clinical PB form ${ }^{29,35,37}$, whereas others have reported a predominance of $\mathrm{MB}^{19,32,33,38,40}$. In the present study, the PB clinical form was most prevalent in both study periods. Surprisingly, no increase in the proportion of $\mathrm{PB}$ cases was identified between the two periods, where an increase can usually be expected when a large increase in the number of cases detected occurs.

Disability grading at diagnosis is extensively used as an epidemiological indicator and as a tool for clinical assessment. The increase in the percentage of cases with DG ratings at diagnosis points to the probable involvement of health services fulfilling and performing this control action more effectively. The value obtained for this parameter is regarded as regular as a rating of health care quality and for monitoring results of the $\mathrm{LCA}^{5}$.

The high percentage of cases lacking disability rating records, especially during the preintegration period, attests to the fact that physical disability ratings is an LCA, which presents problems in quality and registration of assessments ${ }^{27}$. Although a slight increase in the proportion of cases with DG rated at diagnosis was seen in the postintegration period in this investigation, other Brazilian studies have confirmed a rise, followed by a fall, in the proportion of DG 2 ratings during the period of postintegration of LCA as a result of the measures put in place $^{16,26,30}$. 
Although a lower number of cases lacking registration of disability grade was found during the postintegration period both at diagnosis and at end of MDT, indicating a slight improvement in this component of the program, the percentage attained remains low. The finding of lower proportions of cases with DG ratings at the end of MDT is consistent with the results of other studies ${ }^{30,41,42}$. When analyzed individually by year, the DG records do not reach the minimum value required to calculate the indicator for proportion of DG2 among patients concluding $\mathrm{MDT}^{5}$. This problem may be due, in part, to patients not returning to the service for formal discharge. However, it is likely that this problem is largely attributed to the low importance placed on the registration of follow-up information by health care professionals and information services. The low levels of registration of physical disability at conclusion of MDT found in the present study were similar to those identified by other studies ${ }^{30,42}$. This limited checking of DG may have resulted from under-registration of data and indicates that this activity has not yet been incorporated satisfactorily into the routine practice of the services.

The domiciliary contact examinations for new cases diagnosed is one of the main strategies of achieving early diagnosis and help reduce transmission of the disease $\mathrm{e}^{43,44}$.

According to the $\mathrm{WHO}$, estimated risk of relapse after introduction of MDT is $1.1 \%$ for $\mathrm{PB}$ and $0.8 \%$ for $\mathrm{MB}^{45}$. With regard to the admission of relapsing cases, the number of relapses exceeded expected rates, a finding which might be attributed to the organizational structure of the health services ${ }^{46}$, alcohol abuse, nonadherence to treatment ${ }^{47,48}$, diagnostic failure, or to the fact that individuals treated as $\mathrm{PB}$ can subsequently develop generalized $\mathrm{MB}$ lesions after partial improvement in signs and symptoms ${ }^{49}$.

Akin to the findings of the present study, an assessment of integration of LCP into PHC in Betim, Minas Gerais, reported that the surveillance of contacts had not been adequately addressed. Although the program had made advances on other aspects, the lack of registration precluded comparison between contact examination coverage before and after integration ${ }^{30}$.

Consequently, the contact examination was deemed a poor indicator in the cited study for not having attained 50\% contact examination coverage ${ }^{5}$, reflecting a similar situation for the indicator proportion of contacts examined in the present study (37\%). Low coverage of contacts examined also was found by other studies, which reported rates ranging from $11.8 \%$ to $46 \% \%^{42,50,51}$. Compared with the regular range for the parameter, between $50 \%$ and $74.9 \%$ of contacts examined $^{5}$, Dessunti ${ }^{52}$ and Fuzikawa ${ }^{30}$ obtained values of $51 \%$ and $61.7 \%$, respectively. These values were close to the means found for Brazil (54\%) and State of Sergipe (61.8\%) in a national survey assessing the years 2001 to 2008 . These results served to highlight the shortcomings of this control action in Brazil. Only the States of São Paulo and Espírito Santo attained proportions deemed good for the parameter, registering $78.3 \%$ and $75.5 \%$ of contacts examined, respectively ${ }^{53}$. However, a higher level of local organization and more effective priority given to contact surveillance have led to higher rates in some Brazilian municipalities such as Fortaleza, State of Ceará, where, in a single year, the contact examination coverage increased to $76 \%$ as a result of an integral care program for those with leprosy in the region ${ }^{54}$.

In terms of number of examined contacts registered, the postintegration period showed a statistically significant increase in the number of cases detected by contact examinations, reiterating the fundamental importance of this activity.
Finally, another relevant finding was the reduction in percentage of treatment default during the postintegration period. However, it should be noted that this percentage is limited in that it does not take into account patient cohorts but, rather, patient outcomes on the register each year.

The raw overall rates of leprosy detection in Aracaju were higher than the rates reported for Brazil as a whole, thus confirming the seriousness of the local epidemic. The shifts observed during the years studied indicated an increase in the rates of detection in general, and among individuals younger than 15 years, for the period following integration of the leprosy control actions in the municipality, suggesting increased access to health services. The lower number of defaults indicate higher adherence to treatment, suggesting improved access and presumably greater treatment quality after integration of the LCP in PHC.

However, the other operational indicators show that the family health care services have not remedied the previous shortcomings in actions pivotal to achieving the envisaged outcome and impact of the leprosy program, namely, surveillance of contacts and disability diagnosis and prevention activities. The performance profile of the leprosy program observed in this study resembles that of several other Brazilian municipalities studied, showing that family health care has a long way to go to achieve its goals of effective integration, even for a priority target such as leprosy after many years of integration.

\section{ACKNOWLEDGMENTS}

The authors would like to express their thanks to Arleide Franco de Jesus, Eliane Aparecida do Nascimento, Marco Aurélio de Oliveira Góes (State Secretariat for Health of Sergipe), and Fabrizia Tavares (Municipal Secretariat for Health of Aracaju) for granting access to the data and for collaboration in this study.

\section{CONFLICT OF INTEREST}

The authors declare that there is no conflict of interest.

\section{FINANCIAL SUPPORT}

This study was funded by the Pan-American Health Organization through the support program for research in tropical diseases TDR/PAHO/WHO (Project Identifiers: PAHO 300 SGP0941; PAHOERC REF NO PAHO-2009-11-0017.R1) and by the National Council of Scientific and Technological Development (CNPq).

\section{REFERENCES}

1. Ministério da Saúde. Portaria No $1073 /$ GM de 26 de setembro de 2000 . Published no D.O.U. - 188-E - pg 18 -Seção 1 - 28 de setembro, Brasília; 2000.

2. Almeida PF, Giovanella L, Mendonça MHM, Escorel S. Desafios à coordenação dos cuidados em saúde: estratégias de integração entre níveis assistenciais em grandes centros urbanos. Cad Saude Publica 2010; 26:286-298.

3. Secretaria Municipal de Saúde. Coordenação de Vigilância Epidemiológica. Relatório: epidemiologia da hanseníase. Aracaju; 2006.

4. Ministério da Saúde. Secretaria de Atenção à Saúde. Departamento de Atenção Básica. Vigilância em saúde: dengue, esquistossomose, hanseníase, malária, tracoma e tuberculose. Brasília; 2007.

5. Ministério da Saúde. Portaria n 3.125, de 07 de outubro de 2010. Published no D.O.U. nº 198, p. 55 - Seção 1 - 15 de outubro, Brasília; 2010. 
6. Ministério da Saúde. Secretaria de Vigilância em Saúde. Departamento de Vigilancia Epidemiológica. Programa Nacional de Eliminação da Hanseníase. Plano Nacional de Eliminação da Hanseníase em nível municipal 2006-2010. Brasília; 2006.

7. Ministério da Saúde. DATASUS [Intenet]. Brasília. [cited 2010 Jun 27] Available from: http://tabnet.datasus.gov.br/.

8. World Health Organization. Leprosy (Hansen disease). Report by the Secretariat. EB126/2010/REC/2. WHO; 2010.

9. Ministério da Saúde. Secretaria de Vigilância em Saúde. Departamento de Vigilância Epidemiológica. Relatório de gestão do Programa Nacional de Controle da Hanseníase (PNCH): maio de 2007 a dezembro de 2008. Brasília; 2009.

10. Meima A, Richardus JH, Habbema JDF. Trends in leprosy case detection worldwide since 1985. Lepr Rev 2004; 75:19-33.

11. World Health Organization. Global leprosy situation, 2009. Wkly Epidemiol Rec 2009; 33:333-340.

12. Lockwood DNJ, Suneetha S. Leprosy: too complex a disease for a simple elimination paradigm. Bull World Health Organ 2005; 83:230-235.

13. Penna MLF, Penna GO. Trend of case detection and leprosy elimination in Brazil. Trop Med Int Health 2007; 12:647-650.

14. Penna MLF, Oliveira MLW, Penna GO. The epidemiological behaviour of leprosy in Brazil. Lepr Rev 2009; 80:332-344.

15. Cunha SS, Rodrigues LC, Moreira S, Carvalho LC, Barreto ML, Dourado I. Upward trend in the rate of detection of new cases of leprosy in the State of Bahia, Brazil. Int J Lepr Other Mycobact Dis 2001; 69:308-317.

16. Cunha MD, Cavaliere FAM, Hércules FM, Duraes SMB, Oliveira MLW, Matos HJ. Os indicadores da hanseníase e as estratégias de eliminação da doença, em município endêmico do estado do Rio de Janeiro, Brasil. Cad Saude Publica 2007; 23:1187-1197.

17. Hinrichsen SL, Pinheiro MRS, Juca MB, Rolim H, Danda GJN, Danda DMR Aspectos epidemiológicos da hanseníase na cidade de Recife, PE em 2002. An Bras Dermatol 2004; 79:413-421.

18. Figueiredo IA, Silva AA. Aumento da detecção de casos de hanseníase em São Luis, Maranhão, Brasil, de 1993 a 1998. A endemia está em expansão? Cad Saude Publica 2003; 19:439-435.

19. Moreira MV, Waldman EA, Martins CL. Hanseníase no Estado do Espírito Santo, Brasil: uma endemia em ascensão? Cad Saude Publica 2008; 24:1619-1630.

20. Silva Sobrinho RA, Mathias TAF. Perspectivas de eliminação da hanseníase como problema de saúde pública no Estado do Paraná, Brasil. Cad Saude Publica 2008 ; 24:303-314.

21. Opromolla PA, Dalben I, Cardim M. Análise da distribuição espacial da hanseníase no Estado de São Paulo, 1991-2002. Rev Bras Epidemiol 2005; 8:356-364.

22. Ferreira IN, Alvarez RRA. Hanseníase em menores de quinze anos no município de Paracatu, MG (1994 a 2001). Rev Bras Epidemiol 2005; 8:41-49.

23. Imbiriba ENB, Silva Neto ALD, Souza WVD, Pedrosa V, Cunha MDG, Garnelo L. Social inequality, urban growth and leprosy in Manaus: a spatial approach. Revista Saude Publica 2009; 43:01-08.

24. Lana FCF, Amaral EP, Lanza FM, Lima PL, Carvalho ACN, Diniz LG. Hanseníase em menores de 15 anos no Vale do Jequitinhonha, Minas Gerais, Brasil. Rev Bras Enferm 2007; 60:696-700.

25. Pimentel MIF, Andrade M, Valle CLP, Xavier AGM, Bittencourt ALP, Macedo LFS. Descentralização do diagnóstico e tratamento da hanseníase no estado do Rio de Janeiro: avanços e problemas. Hansen Int 2004; 29:94-100.

26. Mastrangelo G, Scoizzato L, Fadda E, Silva GV, Santos LJ, Cegolon L. Epidemiological pattern of leprosy in an endemic area of North-East Brazil, 1996-2005: the supporting role of a Nongovernmental Organization. Rev Soc Bras Med Trop 2009; 42:629-632.

27. Oliveira MLW, Grossi MAF, Oliveira CF, Sena Neto SA, Daxbacher E, Penna GO. Commitment to reducing disability: the brazilian experience. Lepr Rev 2010; 81:342-345.

28. Varkevisser CM, Lever P, Alubo O, Burathoki K, Idawani C, Moreira TM, et al. Gender and leprosy: case studies in Indonesia, Nigeria, Nepal and Brazil. Lepr Rev 2009; 80:65-76.

29. Barro MPAA. Avaliação da situação da hanseníase no município de Londrina de 1997 a 2001: aspectos epidemiológicos, operacionais e organizacionais. Hansen Int 2004; 29:110-117.

30. Fuzikawa PL. Avaliação da descentralização das ações de controle de hanseníase no município de Betim/mg: prevenindo incapacidades? [Masters Dissertation]. [Belo Horizonte]: Universidade Federal de Minas Gerais; 2007. 118 p.
31. Magalhães MCC, Rojas LI. Diferenciação territorial da hanseníase no Brasil. Epidemiol Serv Saude 2007; 16:75-84.

32. Lana FCF, Lima RF, Araújo MG, Fonseca PTS. Situação epidemiológica da hanseníase no município de Belo Horizonte/MG - Período 92/97. Hansen Int 2000; 25:121-132.

33. Lana FCF, Meléndez JGV, Branco AC, Teixeira S, Malaquias LCC, Oliveira VAC, et al. Transmissão e Controle da Hanseníase no Município de Governador Valadares/MG - Período de 1990 a 2000. Hansen Int 2002; 27:83-92.

34. Lana FCF, Lanza FM, Velásquez-Melendez G, Branco AC, Teixeira S, Malaquias LCC. Distribuição da hanseníase segundo sexo no Município de Governador Valadares, Minas Gerais, Brasil. Hansen int 2003; 28:131-137.

35. Prata PB, Bohland AK, Vinhas SA. Aspectos epidemiológicos da hanseníase em localidades do Estado de Sergipe, Brasil, período de 1994-1998. Hansen Int $2000 ; 25: 49-53$.

36. Arantes CK, Garcia MLR, Filipe MS, Nardi SMT, Paschoal VD. Avaliação dos serviços de saúde em relação ao diagnóstico precoce da hanseníase. Health services assessment of early leprosy diagnosis. Epidemiol Serv Saude 2010; 19:155-164.

37. Góes MAO, Sales SOC, Vicente TAR. Perfil clínicoepidemiológico da hanseníase no município de Aracaju/SE no período de 1996 a 2003. Rev Soc Bras Med Trop 2004; 37 (supl I):297.

38. Conte ECM, Magalhais LCB, Cury MRCO, Soubhia RMC, Nardi SMT, Paschoal VD, et al. Situação Epidemiológica da hanseníase no município de São José do Rio Preto. Arq Cienc Saude 2009; 16:149-154.

39. Gomes CCD, Pontes MAA, Gonçalves HS, Penna GO. Perfil clínico-epidemiológico dos pacientes diagnosticados com hanseníase em um centro de referência na região nordeste do Brasil. Anais Bras Dermatol 2005; 80 (supl 3):283-288.

40. Santos LP, Rabay FO. Perfil epidemiológico da hanseníase no município de Taubaté - SP no ano de 1999. Hansen Int 2001;26:112-116.

41. Miranzi SSC, Pereira LHM, Nunes AA. Perfil epidemiológico da hanseníase em um município brasileiro, no período de 2000 a 2006. Rev Soc Bras Med Trop 2010; 43:62-67.

42. Aquino DMC, Santos JS, Costa JML. Avaliação do programa de controle da hanseníase em um município hiperendêmico do Estado do Maranhão, Brasil, 1991-1995. Cad Saude Publica 2003; 19:119-125.

43. Matos HJ, Duppre N, Alvim MFS, Sarno EN, Struchiner CJ. Epidemiologia da hanseníase em coorte de contatos intradomiciliares no Rio de Janeiro (1987-1991). Cad Saude Publica 1999; 15:533-542.

44. Ignotti E. O paradoxo dos indicadores de monitoramento e eliminação da hanseníase. [Doctors Thesis]. [Rio de Janeiro]: Escola Nacional de Saúde Pública Sergio Arouca; 2004. 117 p

45. World Health Organization. The Leprosy Unit, WHO. Risk of relapse in leprosy. Indian J Lepr 1995; 67:13-26.

46. Ferreira SMB, Ignotti E, Gamba MA. Factors associated to relapse of leprosy in Mato Grosso, Central-Western Brazil. Rev Saude Publica 2011; 45:756-764.

47. Brown RL,DimondAR, HuliszD, Saunders LA, BobulaJA.Pharmacoepidemiology of potential alcoholprescription drug interactions among primary care patients with alcohol-use disorders. J Am Pharm Assoc 2007; 47:135-139.

48. Ignotti E. Ignotti E, Andrade VLG, Sabroza PC, Araújo AJG. Estudo da adesão ao tratamento da hanseníase no município de Duque de Caxias - Rio de Janeiro: "abandonos ou abandonados". Hansen Int 2001; 26:23-30.

49. Fleury RN. Recidivas em hanseníase. Hansen Int 2006; 31:5-6.

50. Amorim AA, NOgueira DMB, Luz VLES, Alencar CH. Fatores determinantes para baixa cobertura e qualidade da avaliação de contatos de hanseníase pela estratégia saúde da família no município de Teresina, Piauí. Hansen Int 2010; 35 (suppl 1):97.

51. Morais SG, Rodrigues FP, Branco AC, Malaquias LCC, Cypriano RLB, Estevez MF, et al. Vigilância dos contatos intradomiciliares de hanseníase em Governador Valadares/MG no período de 2001 a 2006. Hansen Int 2010; 35(suppl 1):128.

52. Dessunti EM, Soubhia Z, Alves E, Aranda CM, Barro MPAA. Hanseníase: o controle dos contatos no município de Londrina-PR em um período de dez anos. Rev Bras Enferm 2008; 62 (spe):689-693.

53. Ministério da Saúde. Secretaria de Vigilância em Saúde. Departamento de Vigilância Epidemiológica. Hanseníase no Brasil - dados e indicadores selecionados. Brasília; 2009.

54. Alencar MJF, Mangueira JO, Novaes MC, Paiva RAC, Vasques GRS, Melo ILA, et al. "INTEGRAHANS": potencialização de casos novos na atenção primária em Fortaleza/CE. Hansen Int 2008; 33(suppl 1):99. 